\title{
Ameen Rihani's Visionary Support for Women a Century Ago
}

\author{
S. Karam
}

\begin{abstract}
Ameen Fares Rihani (1876-1940), a LebaneseAmerican prophetic writer and social activist, is widely looked at as a forerunner of modernization. As a staunch activist, his prolific writings were dedicated to humanity in general and women in specific-he was aware of the extent to which women suffered from oppression in the East. Through his writings, Rihani displays a profound interest in women's issues, encouraging their search for independence and modern identity. Consequently, the profile he delineated for women a century ago is about to be realized in our epoch. This paper will exhibit the way Rihani acts as a spokesperson on woman's behalf, emphasizing her voice and focusing on her concerns, thus increasing everyone's consciousness of her educational, economic, and social rights. Finally, it will illustrate the degree to which Rihani, as an irrefutable social reformer, offers matter-of-fact proposals that enable women to attain liberation. This is primarily witnessed in his rhetorical flourishes in The White Way and the Desert-written in English at the age of 20-and his collection of essays, Al Qawmiyyaat (Nationalisms), written in Arabic; both books express his contemporary vision of an independent modern woman.
\end{abstract}

Index Terms-Ameen Fares Rihani, plan for emancipating women, women and economy, women and education, women and society.

\section{INTRODUCTION}

"I say as long as she has a tongue let her speak; as long as she has ears let her hear; as long as she has eyes let her see; and as long as she has brains let her think" (A. F. Rihani, 1876-1940).

"Those who deny freedom to others deserve it not for themselves" (Abraham Lincoln, 1809-1865).

An Arab-American devoted human activist, Ameen Fares Rihani (1876-1940), is a pioneer of modernization, globalization, and universalism. Due to his multicultural upbringing, and after oscillating between the two contradictory realms of the East and West since the age of 12 , he became obsessed with fostering social reform. Rihani assumes the task of a social reformer in order to rescue families and societies from stagnant regression. Consequently, he wishes to restructure man persuaded that "Reforming the individual leads to the reformation of the

Manuscript received May 5, 2013; revised July 12, 2013.

Savo Karam is with the University Louaize, Lebanon (e-mail: savokaram@hotmail.com/savo.karam@ndu.edu.lb). nation ..." [1]. He believed that the Oriental woman should abandon the cocoon of outdated traditions in order to achieve independence, thus assuming the more useful role of a contemporary woman participating in shifting global transformations.

Calling for their liberation more than a century ago, Rihani urged women to discard their customary passivity and, instead, actively participate in the social, educational, and economic aspects of life. More than just playing a complimentary role, Rihani desired women to be equal to men, significantly eliminating the gender discrimination that had existed for centuries in both East and West. He fervently desired to end the never-ending gender feud, rushing to crusade in defense of femininity. To Rihani, a woman is identical to a man: "Now in my opinion woman is not the inferior quality of man ..." [2]. He considers that women are man's equal in various fields and praises America's social makeup that supports a woman's rights.

Through his oeuvre, Rihani shows an insightful awareness of women's concerns. In my paper, I will focus on Rihani's arguments supported by numerous examples and persistent repetition in two of his books: The White Way and the Desert and Al Qawmiyyaat (Nationalisms) and discuss how Rihani raises women's voice by focusing on their concerns, thus depicting for them the appropriate educational, economic, and social frame. As a final point, I will show how Rihani, as a genuine social reformer, sets practical solutions that permit women to achieve emancipation. This study considers the themes found in the above-mentioned works of crucial significance, especially since they are addressed to both sexes more than a century ago.

As a bilingual writer, Rihani employed both English and Arabic to transmit an identical message to the Orient and Occident concerning women's rights, urging females to exert an arduous struggle for freedom, thus delineating a vital, necessary, and useful role for them in the emerging modern society.

\section{WOMEN AND EDUCATION}

Rihani, at the precocious age of 20 , delivered a brilliant speech in New York concerning women: "Nothing gives me greater pleasure; nothing gives me greater promise to our future than the fact that our women are achieving intellectual and physical liberty" [3]. Rihani is particularly pleased with American women's aim to achieve independence through education, their experiment and exploration with personality development, and support for 
others attempting to disengage from past, burdensome traditions. He foresees the following: "I had a dream that women will not be cursed forever ... that the shadows of superstition will not forever prevail over them; that the mantle of ignorance will not forever clothe them ... that intellect and intelligence will crown their lives ..." [4].

Rihani addresses Eastern women in general and Arab/Lebanese women specifically, inviting them to release and liberate themselves from their humble subservience to religion, spouses, relatives, ignorance, and superstition. He is convinced that moral characteristics such as patience, ethics, obedience, honesty, and loyalty - if possessed in a context of tyranny and oppression - are the deferential traits of slavery. Rihani has faith in the latent possibilities of an Eastern woman; she is capable of multiple achievements once she abandons or transcends the traditional forces that wish to dictate her life: "Our woman is capable of reaching the height of prominence as any other woman of any other nation" [5].

Ignorance, according to Rihani, is a social vice that should be resisted: "Ignorance and fear are twins whose mother is slavery and whose father is oppression ..." he further elaborates: “... ignorance ... is darkness .... [It] is oppression and slavery. It is fanaticism and superstition. It is blind obedience and evil egoism. It is fear, cowardice, and humiliation" [6]. The sole effectual way of removing the burden of ignorance is through educating women who constitute half of the nation and who, in turn, will educate their children, the other remaining half of the nation. Consequently, Rihani wonders: "Are you ready to promote the honor of the nation, /which can prosper only through proper education?" [7].

Women could attain freedom by becoming knowledgeable: "The emancipation of women ... is being achieved through education" [8]. Rihani determines that education is not a choice, but a duty; it should be obligatory; he recommends that females attend schools and universities: "Every girl ... should have a primary and ... secondary education. The advanced girl students should continue their higher education" [9].

Education has to be addressed through non-sectarian institutes. He abhors foreign and sectarian schools and only cherishes national schools - the latter are expected to teach pure freedom, patriotism, nationalism, and unity. Only these national schools are empowered to instill noble principles in the new generation-they have no specific political or religious agenda - their sole aim is to provide a cultural education, knowledge of ethics, and honest guidance.

Rihani acutely believes that a national and didactic revival is essential. Moreover, solely through nonsectarian schools would a woman acquire free speech and love for her homeland, while ignoring political associations that fragment the nation. He even encourages Eastern women to migrate to the West where they would develop a superior identity. America, for instance, would provide them with the opportunity to excel in scientific and intellectual fields: "Now in the name of humanity, in the name of civilization, in the name of justice, why does not the mother ask her daughter to go to school .... Why does not she ask her to migrate to a foreign country, to a civilized world, where her precious rights can be attained ..." [10]. He claims that Oriental women have a better chance to embrace liberty in America since he considers that continent the 'torch of freedom': “... there is our Syrian woman in this country, there she is, just escaping the abhorrent obscurity of the night and appearing in the dawn of a bright and new day" [11].

Enlightening a woman is critical; it allows her to progress and partake in a man's life. How could a woman truly evolve if she is not on the same cultural and educational platform as a man? To Rihani, a woman is unable to be truly equal to a man-entitling her to partnership and teamwork-unless she possesses a similar educational background. Thus, he persuades her to edify herself through schooling and employment; subsequently, she could successfully be the male's associate. In other words, providing a woman with her rights signifies her bona fide participation in the cultural, economic, philosophic, political, and humane evolution of civilization.

Rihani also calls on females to teach their offspring constancy, patience, dignity, pride, and vigor, displaying deference only to one's country and social justice. He, moreover, requests mothers to have a vigorous, dynamic nature and teach their kin the value of having will power. She should also inform them about the significance of national identity and loyalty-both acquired through tolerance or acceptance of fellow-citizen differences. Mothers should be aware of the cruciality of their native language and teach Arabic to their children - the inherited language of their parents and grandparents. In addition, of course, he recommends they dispatch kids to national schools that instill principles of secularism [12].

Rihani urges Oriental women to encourage children to love their homeland since this helps emancipate them. Rihani focuses on the female because she represents the nation's engenderment or birth, and, in that role, is able to ascertain that the new generation of children love and respect their homeland: "You Lebanese mother, you Syrian mother, you Palestinian mother, we call you in the name of the homeland ... you have the capacity to help build the new homeland .... We call you, Mother, and seek your help. You are half the nation; rather, in the case of national formation, you are the whole nation" [13].

\section{WOMEN AND ECONOMY}

Economics is the building block of modern societies; its evolvement ensures the development and sustenance of the country and its people. A nation's economy is based on three pillars: agriculture, industry, and trade, in addition to the importance of schools, through which these three pillars evolve and develop. In order for women to embrace successfully the labor market, they must be educated, well trained, and equipped with talent and expertise. This paper concurs with Niviyin Masad who affirms, "As long as women are not economically empowered, they will never be free" [14]. If a country's finances are solely based on masculine involvement, it is bound to remain 
underdeveloped. It requires the support of all its citizens, including women; only then would the nation become gainfully productive. For this reason, Rihani encourages women to participate in producing national goods. He considers that a woman's participation in the labor market is a good phenomenon - a sign of wellness and vigor-it guarantees a national awakening and enhances financial outcomes. Rihani expresses his pride in wearing a suit woven by the skillful, lucrative effort of his female native compatriots.

Rihani persuades women to seek lucrative employment in order to be independent: national manufactures ought to teach partisanship and willingness to sacrifice for the homeland. Nationwide production has the potential to hire thousands of females; it is a constructive means of preventing the economic slavery women are traditionally victim to. For this reason, he addresses women, stating, "Earn your living ..." [15]. He desires that they become economically autonomous. Besides which, being involved in finances, women would help circulate the national currency, a beneficial factor for the national economy.

Being optimistic about the economic future of women, Rihani not only believes females could be man's equal but also their superior. He is convinced that "... the various branches of art ... the world of journalism, the horizon of literature, the firmament of the drama will forever triumph at the appearance of women who are now and forever ready to cope with men and add to the wealth of the world their skills and genius" [16].

A woman has the right to involve herself in the labor market; this guarantees her achievement of equality with her male partner. A female would not progress - and neither would the society - unless she exercises her national rights by working jointly with her opposite gender; similar to the West where women are employed in factories helping men produce vital commodities. They also work in restaurants, plow land, and even, when required, join combat unitsanalogous to Russian and American women that participate in warfare.

\section{WOMEN AND SOCIETY}

Rihani's ideas about defending women's rights aim at benefiting society. He wished to defend women's right because in the East - the chief example of existing patriarchal societies - they are restricted and victimized by men. He realizes, however, not merely men oppress women; they are also stifled by religion, society, and traditions. Rihani truly believes that "the status of woman, fashioned and upheld by man for centuries, must change" [17]. His notion about social freedom and justice is best witnessed in his books. For instance, Juhan, the protagonist of Rihani's novelette Juhan, asserts, "No longer shall we submit to his tyranny, whether a husband, a brother, a father, or a sovereign ruler" [18]. Likewise, the Oriental woman Sarah in Zanbaqat-ul Ghawr (The Lily of the El-Ghore) is a revolutionary example of an Oriental woman who refuses to succumb to the whims of masculinity and is determined to become independent. In the same manner, Mariam is another instance of a rebellious figure in the novel that possesses sovereignty and experiences a painful struggle against restricting social norms. Her words such as "Freedom is sacred, Father" [19] symbolize her motto-an unending joust to retain independence vis-a-vis a male competitor.

Since Rihani's main objective is to reform society, he addresses the issues in the East leading to the weakening of women such as illiteracy, ignorance, submissiveness, and adherence to outdated traditions and superstitions. He confronts such corrupting issues with clarity, boldness, and emphasis. For instance, Rihani praises Turkish women for their intrepid rebellious act of unveiling in public. To him, this is a sign of freedom; he views it as an attempt to keep pace with American females and hopes that other Eastern females will follow suit.

Rihani urges women to participate in the social aspects as well as the cultural and economic fields of life. However, he also appreciates the female's traditional role of homemaker. Rihani praises homemakers and mothers in whose wombs lived leaders, heroes, and champions. He also praises "the combating woman," the woman who cherishes every single member of her family, be it her husband, children, parents, or siblings. He describes her as a generous, sacrificing woman who is a fountain of virtues. This woman deserves to be truly appreciated and treasured since she devotes her entire life tending to others. However, what if she were to be neglected someday-who would assume responsibility for her? She surely deserves a form of aid or material reward; subsequently, Rihani insisted on a decree entitling her to privileges and rights.

In 1935, two years after Rihani wrote the essay, "The Combating Woman," the American social security law to protect the housewife was enacted [20]. However, he does not accept that a woman's best function is that of remaining in her domicile, but invites her, instead, to seek employment. She should seek to undergo self-development in tandem with the country's development. Her real status is not merely being a homemaker; she requires other aspirations. She has "... to help to improve ... [her] kind ... [and] take an interest in the affairs of the community and the welfare of the race" [21]. In other words, a woman must assume the effective role of assisting humanity.

Rihani expects a moral, spiritual, and ethical revolution in Eastern life for the sake of progress and development. He believes that cultural progress exists because of social, political, and religious freedom; in other words, for an autonomous nation to advance, its citizens ought to be granted freedom of thought, speech, and action. Consequently, the Oriental woman should seek liberation by abandoning the cocoon of superstition and slavery; regardless of the fact that she might have to forsake certain aspects of her traditional moral upbringing.

In delineating a modern woman's profile, Rihani asks a woman to be simple in her social life and not blindly follow Western fashions; she must be moderate, humble, and prudent. He encourages her to marry the person she desires. He warns that if a woman is prevented from choosing her soul mate - and subjected to blind obedience - the trait of 
slavery and compliance would sprout not only in herself but also in her offspring. Rihani's thinking was highly influenced by the American women's movement that called for reforms. Rihani's view is that a woman has freedom of choice; she should not be pressured into an objectionable marriage; she has the right to maintain a relationship with the man of her choice [22]. Marriage creates communal bonds, and any social dysfunction leads to an eventual rupture of the social contract. This, in turn, would negatively affect children, the regrettable victims of any unsuccessful marital union. For this reason, to Rihani, true love is the prerequisite of a successful marriage [23].

In The Book of Khalid, Rihan expresses his frustration towards the clergy who refuse to approve of the marriage between Khalid and his cousin Najma even though they are in love. Reverend Farouche attempts to persuade Najma's father that Khalid is not suitable for his daughter, which obliges Najma to leave Khalid and marry someone whom she does not love [24]. That is why Rihani exhorts females to “... find [their] own husband ..." [25]. He advises women to overcome marital problems by perseverance and surmount depression when faced with calamities; disturbing as life is, optimism and patience ought to prevail.

Empowering women leads to the development of society worldwide: “... women's equality is a prerequisite for development," says Kofi Annan (2001). Writers, thinkers, and social activists have always stressed the importance of women's role. The issue of women's rights gradually improves with time; women are increasingly granted decision-making privileges. Rihani encourages women to resist corruption and age-old traditions, transcend calamities, and adopt what is novel, contemporary, and positive in order to develop a social identity.

\section{EMANCIPATION OF WOMEN}

Rihani had always been obsessed with the notion of freedom. He personifies this abstract term in his poem "Freedom: My Companion" as his "traveling companion" and the "subject and predicate of his life" (11. 1-2). He further elaborates in the same poem: "I heard about her as a child;/ I adored her as a young man;/ And I worshiped her as an old man./ She became a part of my life" [26].

Through his oral and literary discourse, Rihani established basic principles for the female liberation movement after his remarkable analysis of the Eastern women's status. The freedom that interests him is founded on reason-he is not an idealist or theorist, but an exceedingly realistic critic. He deems it the appropriate time for a woman to alter her status; it was time to discard discriminatory practices aimed at women. During 1915, the Arabs were negotiating the issue of authorizing women to have a minimal share in education. In the meantime, Rihani had devised a modern profile for the contemporary woman, viewing her as a persona that was not only educated but also independent [27]. Not only Lebanese women had to attain liberty; the Orient in its entirety should consider it a necessity and duty. Juhan, Rihani's spokesperson, persistently reiterates, "I am married to Freedom" [28]. How could a female conceivably be wed to freedom? After closely surveying a woman's status, Rihani is there to illuminate and guide her on the road to liberation. He has a sound plan for her to follow and invites her to partake of it in a gradual, systematic fashion.

Did Rihani succeed in guiding women on the track of emancipation? This study believes he did because he introduced pragmatic solutions and recommendations, which, if applied, would permit women to experience liberty through their participation in public, social, intellectual, political, and economic life. Rihani projects his vision of women's emancipation based on practical guidelines that spur women to assist in various social spheres, positively abetting and shaping the standing of their country and that of humanity:

1) Females should consider it a duty to possess a rebellious spirit and obsession concerning liberty. They should be convinced of their right to proclaim their individual independence. Rihani calls for a moral and intellectual revolution that shuns fear, ignorance, humiliation, and cowardice through education and involvement in various facets of life: art, drama, science, literature, journalism, business, and other professional fields.

2) They should triumph over obstacles that hinder their progress towards freedom. Rihani suggests that women replace their fear with resilience, shunning religious, social, and ancient traditional shackles in addition to bigotry and prejudice. He advises them to adopt patience, consistency, courage, will, and perseverance - priceless qualities that should also be imparted to their children.

3) They should welcome the idea of migrating to other countries in order to confirm their new identities, especially to nations where freedom is highly valued.

4) They have to be outspoken and freely express their opinions and beliefs.

5) They should be ready to execute decisive actions, believe in self-development, and work on enhancing their skills, thus allowing the world to benefit from their expertise, talent, and intelligence.

6) They should attempt to satisfy their yearnings, exercise their will, and enjoy their sovereignty: “... a girl who insists upon having her own way... would exercise her own will; she would be free to go wherever she is pleased and do whatever she is pleased. For example, a woman should not be pressured into an arranged marriage, and should, instead, be allowed to freely choose her male partner.

7) They should empathize with those of the same sex, demonstrating solidarity in order to achieve their aims. They should set their own guidelines and be prepared to act upon them.

Rihani proposed the above in order to accelerate change. His proposals provided women with sufficient sovereignty and confidence that enabled them to act with emancipator impunity. Rihani makes women aware that their freedom is innate-nobody can deprive them of it. They are entitled to it. 
Significantly affected by the French Revolution and principles of Western civilization in addition to an intellectual renaissance prevalent during his lifetime, Rihani tackles women's concerns in depth, placing women's issues that have always captured his attention in an international frame. He urges a woman to be active in various fields, so she could strengthen her position, establish her unique identity, and reinforce a national revitalization. He defends a woman's rights and needs, rouses the Oriental woman from her submissiveness, urging her to engage in the socioeconomic and cultural life. He prods her to benefit from Western civilization - particularly in the field of science and education-in order to narrow the existent gender differences.

At a time of globalization and modernization, women are ready for a change and experience a patent difference. No doubt, this is the right century for women to be heard. Rihani, 'holding the torch' to emancipate women from the bleakness of ignorance and superstition, will definitely have many Eastern and Western followers. Being remarkably buoyant and positive about women's prospects, Rihani predicts, "I anticipate a great future for our women" [29]. This century is in need of outstanding women who could leave an immortal imprint in the field of science, art, business, and other domains. To Rihani these intellectual women will be remembered since "... they will forever triumph in the throne of glory crowned and sceptered with the labor of their brains, as long as the globe tends to exist" [30].

As an activist, Rihani desires women to acquire their equal share in this modern era; he wishes to eradicate the notion that they are male-dominated. If women are not permitted to share in a variety of lifestyles, sustained progress will not be attained-due to the past inexcusable, 'man-made' disparities between the sexes. In fact, promoting women issues and an awareness of their rights is crucial not merely for females but also for the society. In the era of globalization, it is a shame if both genders are unable to participate in an impartial, unprejudiced, and equitable manner in different aspects of life.

Rihani's farsighted, prophetic vision concerning women's rights that he uncovered more than a hundred years ago could be summarized in the following:

I am optimistic because woman, who was tied down by the whims of the ruler, the legislature and the wealthy man, will become one day one of the rulers, legislatures and economists, and she will be able to give her consent in marriage. Women constitute half of the dormant nation, but now they will rise from behind the curtains of injustice and oppression, they will leave their bedrooms and join the men in their jobs and their dreams [31].

It is correct to deduce that the matter of women liberation for Rihani is emphatically not a myth but a sustainable truth and reality. This paper described the way in which he perceived women's concerns in his relatively traditionalist era, anticipating the changes that would occur in a future, defiant century, and as Douaihi confirms in his essay "Women's Issues in Rihani's Literature” “... Rihani’s approach to women's concerns is a part of his humane call for worldwide revolution and change" [32].

\section{REFERENCES}

[1] A. F. Rihani, Ar-rihaniyyaat, The Rihani Essays, R. Z. Baalbaki, Trans., Washington D.C.: Platform International, 2010, pp. 138.

[2] A. F. Rihani, The White Way and the Desert, Washington D. C.: Platform International, 2002, pp. 88.

[3] A. F. Rihani, The White Way and the Desert, Washington D. C.: Platform International, 2002, pp. 87.

[4] A. F. Rihani, The white way and the Desert, Washington D. C.: Platform International, 2002, pp. 87-92.

[5] A. F. Rihani, The White Way and the Desert, Washington D. C.: Platform International, 2002, pp. 89.

[6] A. F. Rihani, Attatarrof wal islaah, Extremism and Reform, N. M. Diab, Trans., Lebanon: n. p., 1997, pp. 20, 31.

[7] A. F. Rihani, Hutaf ul awdiya, Hymns of the Valleys, N. Oueijan, Trans.), USA: Georgias Press, 2002, pp. 69.

[8] A. F. Rihani, The White Way and the Desert, Washington D. C.: Platform International, 2002, pp. 88-89, 104.

[9] A. F. Rihani, The White Way and the Desert, Washington D. C.: Platform International, 2002, pp. 159.

[10] A. F. Rihani, The White Way and the Desert, Washington D. C.: Platform International, 2002, pp. 88, 90.

[11] A. F. Rihani, The White Way and the Desert, Washington D. C.: Platform International, 2002, pp. 91.

[12] A. F. Rihani, Al qawmiyyaat, Nationalisms, Beirut, Lebanon: Dar Al Jeel, 1987, pp. 174, 204, 277-280.

[13] A. F. Rihani, Attatarrof wal islaah, Extremism and Reform, N. M. Diab, Trans., Lebanon: 1997, pp. 60.

[14] N. Masad, Women's Rights, Beirut, Lebanon: The Arab Institution for Human Rights, 2004, pp. 7.

[15] A. F. Rihani, The White Way and the Desert, Washington D. C.: Platform International, 2002, pp. 100.

[16] A. F. Rihani, The White Way and the Desert, Washington D. C.: Platform International, 2002, pp. 92.

[17] A. F. Rihani, The White Way and the Desert, Washington D. C.: Platform International, 2002, pp. 99.

[18] A. F. Rihani, Juhan, Lebanon: NDU Press, 2011, pp. 16.

[19] A. F. Rihani, Zanbaqat-ul ghawr, The lily of el-ghore, Beirut, Lebanon: Dar Al Jeel, 1989, pp. 321.

[20] D. Hoskins, "US social security at 75 years: An international perspective," Social Security Bulletin, vol. 70, no. 3, August 2010, pp. 84-85.

[21] A. F. Rihani, The White Way and the Desert, Washington D. C.: Platform International, 2002, pp. 93-94.

[22] A. F. Rihani, Rasa'l ameen arrihani al arabiyya, The Arabic letters of Ameen Rihani, Beirut, Lebanon: Dar Al Jeel, 1989, pp. 265.

[23] A. F. Rihani, Adab wa fan, Literature and art, Beirut, Lebanon: Dar Al Jeel, 1989, pp. 13.

[24] A. F. Rihani, The Book of Khalid, Beirut, Lebanon: The Rihani House, 1973, pp. 197-198.

[25] A. F. Rihani, The White Way and the Desert, Washington D. C.: Platform International, 2002, pp. 100.

[26] A. F. Rihani, Hutaf ul awdiya, Hymns of the Valleys, N. Oueijan, Trans., USA: Georgias Press, 2002, pp. 67.

[27] N. Hajjar, “Ameen Rihani's vision of woman's rights between reality and imagination," International Proceedings of Ameen Rihani and Arab Renewal: Challenges of Change in Literature, Thought and Society, ed. Najma Hajjar, Beirut, Lebanon: Center for Arab Unity Studies, 2012, pp. 143.

[28] A. F. Rihani, Juhan, Lebanon: NDU Press, 2011, pp. 14, 72.

[29] A. F. Rihani, The White Way and the Desert, Washington D. C.: Platform International, 2002, p. 88.

[30] A. F. Rihani, The White Way and the Desert, Washington D. C.: Platform International, 2002, pp. 89.

[31] A. F. Rihani, Ar-rihaniyyaat, The Rihani Essays, R. Z. Baalbaki, Trans., Washington D.C.: Platform International, 2010, pp. 342-343.

[32] J. Douaihi, "Women's issues in Rihani's literature," International Proceedings of The Second International Conference on LebaneseAmerican Literary Figures: Ameen Rihani's Arab American Legacy: From Romanticism to Postmodernism, ed. Naji Oueijan, Lebanon: Notre Dame University Press, 2012, pp. 119. 


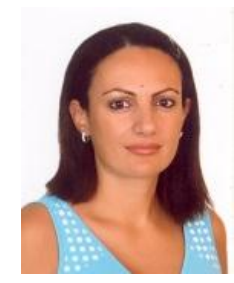

S. Karam was born on July 4, 1972. She is Lebanese. She holds a Ph.D. in English Literature from the Lebanese University. She is currently a member of the International Byron Society and an assistant professor at Notre Dame University (NDU), Lebanon-Faculty of Humanities, Department of English, Translation, and Education. Previously, she was a part-time faculty member at the Lebanese American University (Byblos campus) and the Lebanese University (Tripoli). She is experienced in teaching language and literature. She has published an article titled "Truths and Euphemisms: How Euphemisms Are Used in the Political Arena" in The Southeast Asian Journal of English Language Studies. She has also published an English-Arabic dictionary entitled A Current Dictionary ; a teaching booklet called English for Beginners; and is the author of a book called Ameen Fares Rihani: The Multifold Critic. She participated in various local and international English and Arabic conferences such as "Common Platforms for Bridging World Cultures," "Ameen Rihani's Arab American Legacy: From Romanticism to Postmodernism," "Ameen Rihani and Arab Renewal: Challenges of Change in Literature, Thought and Society," the Austrian Cultural Forum conference called "IMAGES" held in Istanbul, Turkey, and the 38th International Byron Conference held at NDU. Moreover, Dr. Karam participated in an international conference held in USEK University, Lebanon on April 25 and 26, 2013 under the title "Globalized Modernity and Cultural Identity in Arab Emigrant Writings" and in the 39th International Byron Conference that took place in London between July 1 and July 7, 2013 